\title{
Fuchs heterochromic iridocyclitis
}

INSERM

\section{Source}

INSERM. (1999). Orphanet: an online rare disease and orphan drug data base. Fuchs heterochromic iridocyclitis. ORPHA:263479

Fuchs heterochromic iridocyclitis (FHI) is an ocular disease of unknown etiology occurring in a very small percentage (0.5-6.2\%) of uvietis cases, characterized by diffuse iris heterochromia or atrophy, keratic precipitates in the absence of synechiae, and in some cases evolving to glaucoma and vitreous opacities. 